\title{
A review of the Model 5A uranium hexafluoride cylinder
}

Dorning, R.E. II

23 May 1989

Martin Marietta Energy Systems, Inc., Portsmouth, OH (USA). Quality and Technical Services Div.

Reproduced and Distributed by:

U.S. DEPARTMENT OF ENERGY

Office of Scientific and Technical Information

P.O. Box 62

Oak Ridge, TN 37831 


\section{DISCLAIMER}

This report was prepared as an account of work sponsored by an agency of the United States Government. Neither the United States Government nor any agency Thereof, nor any of their employees, makes any warranty, express or implied, or assumes any legal liability or responsibility for the accuracy, completeness, or usefulness of any information, apparatus, product, or process disclosed, or represents that its use would not infringe privately owned rights. Reference herein to any specific commercial product, process, or service by trade name, trademark, manufacturer, or otherwise does not necessarily constitute or imply its endorsement, recommendation, or favoring by the United States Government or any agency thereof. The views and opinions of authors expressed herein do not necessarily state or reflect those of the United States Government or any agency thereof. 


\section{DISCLAIMER}

Portions of this document may be illegible in electronic image products. Images are produced from the best available original document. 


\section{DISCLAIMER}

This report was prepared as an account of work sponsored by an agency of the United States Government. Neither the United States Government nor any agency thereof, nor any of their employees, makes any warranty, express or implied, or assumes any legal liability or responsibility for the accuracy, completeness, or usefulness of any information, apparatus, product, or process disclosed, or represents that its use would not infringe privately owned rights. Reference herein to any specific commercial product, process, or service by trade name, trademark, manufacturer, or otherwise does not necessarily constitute or imply its endorsement, recommendation, or favoring by the United States Government or any agency thereof. The views and opinions of authors expressed herein do not necessarily state or reflect those of the United States Government or any agency thereof.

\section{By}

\section{R. E. Dorning II}

Chemical and Materials Technology Department Quality and Technical Services Division

: May 23, 1989

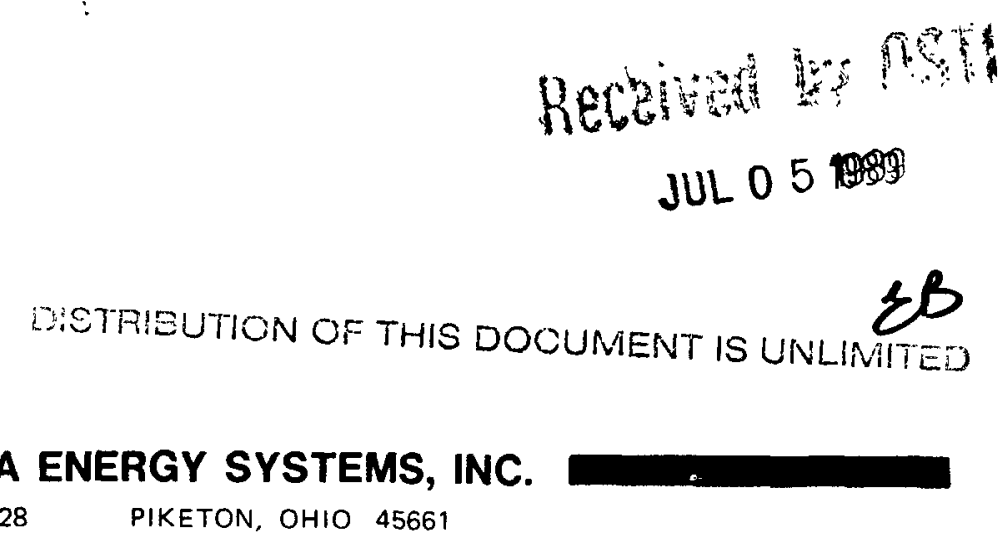

Actıng under Contract DE-AC05-760R00001 with the U.S. Department of Energy 
This report was prepared as an account of work sponsored by an agency of the United States Government. Neither the United States Government nor any agency thereof, nor any of their employees, makes any warranty, express or implied, or assumes any legal liability or responsibility for the accuracy, completeness, or usefulness of any information, apparatus, product, or process disclosed, or represents that its use would not infringe privately owned rights. Reference herein to any specific commercial product, process, or service by trade name, trademark, manufacturer, or otherwise, does not necessarily constitute or imply its endorsement, recommendation, or favoring by the United States Government or any agency thereof. The views and opinions of authors expressed herein do not necessarily state or reflect those of the United States Government or any agency thereof.

\section{DO NOT MICROFILM THIS PAGE}




\section{Distribution}

R. D. Bush

J. G. Crawford

R. E. Dorning (2)

W. E. Limville

A. J. Saraceno

K. W. Schucker

D. A. Shisler

J. E. Shoemaker, Jr.

J. P. Vournazos

Iibrary Services (2)

Central Files (2)

Technical Review (4)

E. W. Gillespie

R. I. Reynolds

W. E. Sykes
MS 1225

MS 2227

MS 2149

MS 2213

MS 2213

MS 1112

MS 1112

MS 1221

MS 3209A

MS 2206

MS 1101

MS 2209

DOE-PEO

PDGP Cl00

PGDP C302 
TABLE OF CONIENTS

Page

SUMMARY $\ldots \ldots \ldots \ldots \ldots \ldots \ldots \ldots \ldots \ldots \ldots \ldots \ldots \ldots \ldots, 4$

INTRODUCIION $\ldots \ldots \ldots \ldots \ldots \ldots \ldots \ldots \ldots \ldots \ldots \ldots \ldots$

MODEL 5A CYLDNDER $\quad \ldots \ldots \ldots \ldots \ldots \ldots \ldots \ldots \ldots \ldots \ldots, 5$

MODEL 5 A MODIFIED $\ldots \ldots \ldots \ldots \ldots \ldots \ldots \ldots \ldots \ldots \ldots, 6$

MODEL 5A MODIFIED "CODE" STATUS $\ldots \ldots \ldots \ldots \ldots \ldots \ldots$.

RITPIURE TESTING OF MODEL 5 A MODIFIED ......... 8

INDEPENDENT CONSUITAANT REVIEW $\ldots \ldots \ldots \ldots \ldots \ldots \ldots . .6$

CURRENT STATUS OF MODEL 5A MODIFIED CYLTNDERS ... 9

APPENDIX I $\ldots \ldots \ldots \ldots \ldots \ldots \ldots \ldots \ldots \ldots \ldots \ldots \ldots \ldots \ldots$

APPENDIX II $\ldots \ldots \ldots \ldots \ldots \ldots \ldots \ldots \ldots \ldots \ldots \ldots \ldots \ldots$ 
Both the Model 5A and 5A Modified five-inch cylinders have been used at the Portsmouth GDP to withdraw, store, and ship highly enriched uranium hexafluoride. As a result of a generic cracking problem with Monel 400 valveboss material, a cylinder modification was implemented in the mid 1970s. This modification resulted in the violation of the ASME "Code" stamp status of the Model 5A Modified cylinder. Hydrostatic testing-to-rupture data indicated that the Model 5A Modified cylinders had ruptured strengths equivalent to that of the original Model 5A cylinders. An independent consultant reviewed the available information and confirmed that the Model 5A Modified cylinders "will with proper maintenance continue to perform satisfactorily for many additional years of service." Based on the test data and consultant's review, DOE approved contimued use of the $5 \mathrm{~A}$ Modified cylinder and also requested procurement of replacement 5B cylinders be expedited. Currently, the 5A modified cylinders are in the production, storage, shipment cycle, and a sufficient number of 5B cylinders has been ordered to accommodate the projected product shipping requirements for the Navy flow.

\section{INTRODUCTION}

The five-inch diameter uranium hexafluoride $\left(\mathrm{UF}_{6}\right)$ cylinder was designed to address nuclear criticality considerations for uranium enrichment greater than 30\% U-235. The design criteria of the five-inch cylinder are presented in Table 1. The five-inch cylinders were fabricated from materials which were shown to resist degradation from the internal and external service envirorments. The five-inch UF 6 cylinder was fabricated acoording to the ASME Boiler and Pressure Vessel code, Division I, Section VIII and was "code" stamped even though the cylinder was not covered by the "Code" due to it's small diameter and volume.

TABLE 1 STANDARDS FOR THE FIVE-INCH CYIINDER

\section{Diameter \\ Overall Length \\ Vessel Iength \\ Wall Thickness \\ Minimum Volume \\ Design Pressure \\ Internal \\ External}

Hydrostatic Test Pressure
5 Inches

45.6 Inches

29.5 Inches

0.25 Inch

0.284 Cubic Feed

200 psi at $250^{\circ} \mathrm{F}$

$22 \mathrm{psi}$ at $250^{\circ} \mathrm{F}$

15 psi at $-120^{\circ} \mathrm{F}$

400 psi 
As part of the manufacturing specification and "Code" stamp procedure, the cylinders were subjected to a mumber of inspections and tests to assure the quality of the cylinder. The welds were visually inspected, as well as spot checked using radiographic techniques in accordance with the ASME "Code" at the time of manufacturing. A 400 pound hydrostatic pressure test (twice the design pressure) was also performed on each cylinder at the time of manufacturing and every five years thereafter, provided the cylinder was empty. If the cylinder is full when the five-year hydrostatic pressure test is cue, the test is performed after empting but prior to refilling the cylinder. In addition to the five-year hydrostatic pressure test cycle, a visual internal and external inspection of the cylinder is performed by a qualified ASME code Inspector at the same interval as the hydrostatic pressure testing. After valve installation, an air/soap test is employed to examine for leaks.

operational tests are also performed on the cylinders prior to filling. These tests include visual external inspection by the operator, and a vacurm leak check. Full cylinders also receive operational tests prior to service. The full and empty cylinders are visually inspected and the valve stem seal and connections are pressure checked and vacunm leak checked.

The five-inch cylinder has undergone a number of designations and modifications since its conception. The original five-inch cylinder, designated as Model 5 or simply five-inch cylinder, was procured by ORGDP. The Model $5 \mathrm{~A}$ was used to denote the Model $5 \mathrm{cylinders}$ which belonged to the Portsmouth Diffusion Plant in the late 1950s. The Model 5A was later modified at Portsmouth in the earler to mid 1970s and became the Model 5A Modified. In 1982, the five-inch cylinder underwent a material of construction change from Monel to nickel and the designation was changed to Model 5B.

\section{Model 5A Cylinder}

The Model 5A cylinder was constructed of Monel 400 (Table 2) and procured as a "Coded" pressure vessel. The Portsmouth compliment of the Model 5A was 1150 cylinders of which approximately 200 currently are in use for long-term storage. During the Model 5A's service life, there was never a design or material failure resulting in a loss of integrity of the cylinder. Two problems were identified during the routine inspections of the Model 5A cylinders. The first problem was attributed to a stress corrosion mechanism as a result of a custamer using the cylinder to cold trap material containing niobium pentafluoride. The problem was detected at the early stage during the internal visual inspection of the cylinder and the cylinder was taken out of service for examination. The customer was informed of the detrimental effects of the niobium pentafluoride on the Monel cylinders and the use of the Model 5A for the cold trapping of the niobium pentafluoride was halted.

The second problem identified was cracking of the valve coupling (boss) during revalving operations, and was generic to all the re-valved 5A cylinders. The cracking resulted from liquid metal penatration of the Monel boss material by cadmium and silver which were constituents of the silver brazing filler metal. The silver and cadmium which had diffused into the 
Monel curing the previous valve installation/removal would concentrate in a second phase along the Monel grain boundaries during revalving operations. This second phase along the grain boundaries embrittles the Monel during colling and cracking occurred. At first, the cracking was not preceived as a serious problem since the cracks were filled with silver brazing material from the revalving operations. However, in the early 1970 s it became unacceptable to permit the usage of a vessel with an obvious crack in one or both bosses.

The corrective action proposed and accepted by the parties involved, was to change the boss material from Monel to nickel which was not susceptible to liquid metal embrittlement by the silver brazing materials. A program was therefore initiated at Portmouth to replace the Monel bosses with nickel bosses. The program used the ASME "Code" as a guideline and the modified cylinders met or exceeded the structural requirements and inspection criteria of the "code." The designation for these "modified" cylinders became the Model 5A Modified. A few of the Model 5A cylinders (around 200) are still in existence.

TABLE 2 MATERTAIS OF CONSTRUCTION FOR THE FIVE-INCH CYITNDERS

\begin{tabular}{l} 
Description \\
\hline Shell \\
Heads \\
Couplings \\
Neck Ring \\
Foot Ring \\
Dip Pipe \\
Support Ring \\
Handles \\
Valve Protector
\end{tabular}

\begin{tabular}{l} 
Model 5A \\
\hline Ni-cu, ASTM B-165 \\
Ni-cu, ASTM B-165 \\
Ni-cu, ASTM B-165 \\
Ni-cu, ASTM B-165 \\
Ni-Cu, ASTM 5-165 \\
Ni-Cu, ASTM B-165 \\
Ni-Cu, ASTM B-165 \\
Ni-Cu, ASTM 5-164 \\
Carbon Steel
\end{tabular}

Model 5A Modified
Model 5A Modified

$$
\begin{aligned}
& \text { Ni-Cu, ASTM B-165 } \\
& \text { Ni-Cu, ASTM, B-165 } \\
& \text { Ni, ASTM B-161 } \\
& \text { Ni-Cu, ASTM B-165 } \\
& \text { Ni-Cu, ASTM B-165 } \\
& \text { Ni-Cu, ASTM B-165 } \\
& \text { Ni-Cu, ASTM B-165 } \\
& \text { Ni-Cu, ASTM B-165 } \\
& \text { Carbon Steel }
\end{aligned}
$$

The 5A Modified cylinders are 5A cylinders which have had the Monel bosses replaced with nickel bosses, consequently, the dimensions and design criteria of the two cylinders are the same. The only difference is the material change from Monel 400 to nickel for the valve bosses (Table 2). There are also a small muber of five-inch cylinders which have had the cylinder head as well as the bosses replaced.

The modification program for changing the Model $5 \mathrm{~A}$ to the Model $5 \mathrm{~A}$ Modified took place over about a ten-year period from the mid 1970s to mid 1980s. The majority of the cylinders were modified within the first few years of the program during routine cylinder maintenance or at rehydro test intervals; the remainder were modified upon emptying. Each cylinder that was modified underwent spot radiographic examination of the welds, visual inspection, and hydrostatic pressure testing to $400 \mathrm{psi}$. The welders were qualified in accordance with the "code." The governing document for cylinders, ANSI-N14.11982, was revised to reflect the material change and to specify nickel bosses for new cylinder procurement. 


\section{Model 5A Modified "Code" Status}

In early 1987, in response to a proposed DOT regulation, a statement was issued by DOE that only "Coded" CYlinders were to be shipped by DOE facilities. At that time it was pointed out that the Model 5A Modified cylinders at Portsmouth were no longer "Code" stamped cylinders. A precursory inquiry was made to the "National Board of Boiler and Pressure Vessel Inspectors" ("Board") to determine the "Code" status of the Model 5A Modified cylinders and what, if anything, could be done to reinstate the "code" stamped status.

The modification of the five-inch cylinder violated the ASME "Code" status of the cylinders in two ways. The change in material required that a shop possess a mamufacturers stamp ("U") to rework the cylinders, and submit design change documentation in order to retain the "Code" status. At the time of reworking, the Portsmouth site did not hold a "U" stamp, therefore, the modified cylinders were no longer "Code" stamped. In 1986, with DOE concurrence, the Portsmouth site applied for a "code" repair stamp ("R"). The application was subsequently approved, thus permitting the repair of "code" stamped of repaired pressure vessels by the Portsmouth facility.

At the time of the modification, the "code" required certification for materials and consumables. The certification could be in the form of material compliance sheets or mill certification. This information is not available for the modifications performed on the five-inch cylinders. As a result of this lack of certification and "U" stamp, the "Board" ruled that the Model 5A Modified cylinders were not "Code" stamped pressure vessels. However, the "Board" indicated that the cylinders might be reinstated to "Code" status in two ways. The first required several actions with the findings submitted to the "Board" for review and a ruling. The actions required encompassed the following: 1) All materials and consumables used on each cylinder would need to be sampled and analyzed for composition, 2) $100 \%$ radiographic inspection of all welds performed without a "Code" stamp, 3) the modification procedures submitted to the "Board" for review including welder certifications, and 4) a certified "Code" inspector to sign off on the materials used and the radiographs. The "Board" would review this information and then make a decision whether the cylinder could be reinstated. This option was not considered viable since the cost of the program would exceed the cost of new cylinders.

The second method to reinstate the "Code" status entailed reworking the cylinders. Since Portsmouth holds an "R" stamp, a reworking of the cylinders under the "R" stamp program would reinstate the "Code" provided the material was changed back to that of the original design (Monel 400). The other rework option would be to have a "U" stamp holder rework the cylinders and submit the design change documentation to the "Board." Neither of the rework options were considered "practical" since the return to Monel 400 would result in a valve boss cracking problem in the future, and the contamination status of the cylinders prohibited the work being done by an outside vendor. 


\section{Rupture Testing of Model 5A Modified}

Because the modified cylinders could not be code stamped, Portsmouth, in 1986, initiated a program to demonstrate the integrity of the Model $5 \mathrm{~A}$ Modified cylinders. Hydrostatic rupture testing was performed at ORGDP and Portsmouth on three modified cylinders and the results compared to those for a test performed by ORGDP on a new Model 5A cylinder in 1966. The test cylinders were chosen to represent the modification techniques employed over the tenyear period. All of the cylinders ruptured in the normal manner for a cylinder hydrostatic-rupture test (longitudinal split in the cylinder shell). None of the cylinders tested showed any evidence of the modification affecting the integrity of the vessel. The rupture pressures compared favorably with that for the new Model 5A rupture test of 1966, Table 3.

\section{TABLE 3 PROOF TEST DATA FOR 5A MODIFIFD CYLTNDERS}

\begin{tabular}{|c|c|c|c|c|}
\hline $\begin{array}{l}\text { Cylinder } \\
\text { Type }\end{array}$ & $\begin{array}{l}\text { Modification } \\
\text { Date }\end{array}$ & $\begin{array}{l}\text { Wall } \\
\text { Thickness }\end{array}$ & $\begin{array}{l}\text { Rupture } \\
\text { Pressure }\end{array}$ & $\begin{array}{l}\text { \& Volume } \\
\text { Increase }\end{array}$ \\
\hline $\begin{array}{l}5 A \\
5 A \text { Modified } \\
5 A \text { Modified } \\
5 A \text { Modified }\end{array}$ & $\begin{array}{l}\text { NA } \\
1986 \\
1979 \\
1977\end{array}$ & $\begin{array}{l}1 / 4^{\prime \prime} \\
1 / 4^{\prime \prime} \\
1 / 4^{\prime \prime} \\
1 / 4^{\prime \prime}\end{array}$ & $\begin{array}{l}8250 \text { psi } \\
7950 \text { psi } \\
7200 \text { psi } \\
8600 \text { psi }\end{array}$ & $\begin{array}{l}- \\
21 \\
21 \\
23\end{array}$ \\
\hline
\end{tabular}

In March of 1987, based upon the results of the rupture testing, DOE approved the shipping of Model 5A Modified cylinders and listed actions to be taken. These actions were to: (1) expedite procurement of replacement cylinders (Model 5B), and (2) to obtain an independent opinion on the contimued use of the Model 5A Modified cylinder (Appendix I).

\section{Independent consultant Reveiw}

In 1987 an independent consultant was hired by Portsmouth to render an opinion on the continued use of Model 5A Modified cylinders. The consultant reviewed the history of the cylinders, the modification procedures, welder certification documentation; spot checked the radiographs, toured the portsmouth welding shop, valve shop, and inspection facilties; and examined the hydrostatic nupture data prior to rendering an opinion.

The conclusion of the independent consultant, in summary, was that the cylinders were no longer a "Code" stamped pressure vessel, however, "the vessels as they now exist will, with proper maintenance, contimue to perform satisfactorily for many additional years of service." A copy of the report is provided in Appendix II. 


\section{current Status of Model 5A Modified Cylinders}

The Model 5A Modified cylinders continue to be an integral part of the high assay operations of the Portsmouth Gaseous Diffusion Plant. The cylinders are being used to withdraw, store, and ship highly enriched UF ${ }_{6}$. The long range plans are to eventually limit the use of these cylinders to "on site" usage after receipt of sufficient Model 5B cylinders to handle the projected shipments of material to the Navy. Presently, 400 Model 5B cylinders have been received with an additional 250 Model 5B cylinders being procurred to accommodate the routine projected shipments.

TR-5-31-89-HHT 
APPENDIX I

Correspondence from DOE authorizing shipment of Model $5 \mathrm{~A}$ modified cylinders. 


\section{Department of Energy}

Oak Ridge Operations

P. O. Box E

Oak Ridge, Tennessee 37831

March 13, 1987
XC: DeVito

Bush

Lermon

Miller

Stalnaker

E0-87-001

Mr. Kenneth $W$. Sommerfeld

Vice President, Enrichment

Oak Ridge Gaseous Diffusion Plant

Martin Marietta Energy Systems, Inc.

P. 0. Box P

Oak Ridge, TN 37831

Dear Mr. Sommerfeld:

HEU CYLINDERS

This is to confirm my telephone conversations with you and your staff regarding resumption of shipments of modified 5A.cylinders, subject to the recommendations in the attachment.

With reference to recommendation 2 in the attachment, please have the independent experts who will render a judgement on the suitability for. use of the $5 \mathrm{~A}$ cylinders also give us an opinion of the "re-codeability" of those cylinders. I would like to know if it is possible for our existing cylinders to be re-stamped before committing funds for replacement cylinders.

It you nave any questions, please give me a call.

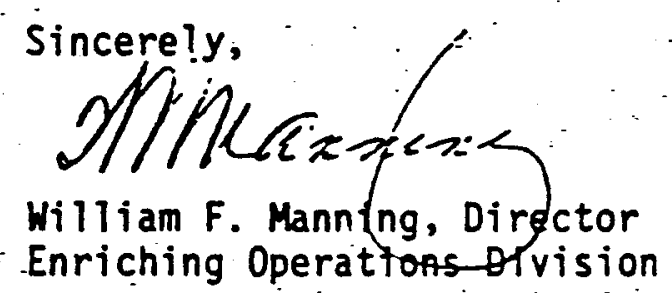

Attachment: Determination RE the Continuing Use, Including Transportation, of the Current Inventory of Five Inch HEU Cylinders

cc: J. W. Bennett, NE-33, GTN-HQ

\&R. G. Donnelly, PORTS

W. L. Walker, EO-20

- E. Gillespie, PEO, EO-25

R. L. Egli, SE-30

D. B. Howard, SE-33

W. A. Pryor, SE-33 
March 11, 1987

\author{
Determination Regarding the Continuing Use, \\ Including Transoortation, of the current Inventory of \\ Five Inch feu cylinders
}

\title{
Issue
}

Should filling, emptying, transportation and other operations continue with current five inch cylinders as required to meet custaner orders?

\section{Background.}

Based upon a recent review of the condition and history of the inventory of five inch cylinders a decision was made to cease transporting those in non-compliance with applicable codes. This decision was not based on any concern for safety or the integrity of the modified cylinders; in fact, the modifications which technically invalidated the code stamp by changing materials of fabrication actually made the cylinders safer.

Contrary to information available at the time, implementation of the decision will not permit adherence to astamer product shipment schedules. Procurement of new cylinders cannot be achieved in time to mitigate the impacts upon custamer deliveries.

Subsequent considerations indicate that filling and emptying operations of cylinders may. present greater risks than transportation operations. All 1150 cylinders were ASME code stamped when manufactured. All but about 160 no longer qualify due to those changes in materials of fabrication (changing from monel to rickel) that technically invalidated the code stamp.

Alteration and repair operations were performed in accordance with ASME Pressure code, Section B, Division 1. Welders were qualified and certified in accordance with ASME Pressure Vessel code, section 9. Procedures were subsequently submitted and an ASME pressure code program "R" stamp was obtained.

All repaired cylinders have been hydrostatically tested to 400 psi which is twice the maximm design pressure of 200 psi. Maximum experienced operating pressure is about 65 psi, which occurs during the liquification process.

Each cylinder receives a 400 psi hydrostatic test every five years, a vacurm and helium leak test prior to filling and a 
visual inspection prior to shipping. There have never been any cylinder failures. All repairs were initiated as a result of the test and inspection program. A repaired cylinder failed that was intentionally pressurized to $7900 \mathrm{psi}$ on March 7, 1987. An unaltered cylinder was previously tested to destruction at 8000 psi. Both failures were langitudinal splits in the cylinder side walls (away fram the repaired area of the modified cylinder).

There are aurrently no DOE, DOT or NRC regulations requiring that these cylinders be coded.

\section{Recommendations}

Recognizing that (1) departure from the ASME pressure vessel code is a technicality, (2) the results of pressure tests demonstrated that failure would not be in the area of rework, i.e., the above noted failures ocairred in the cylinder wall in the two cylinders that were tested to destruction at approximately 8000 psi, as compared to the normal maximm operating pressure of $65 \mathrm{psi}$, and (3) a continuing inspection program is in place, we recammend the following:

1. Shipments should continue utilizing existing cylinders.

2. By April 15, 1987, a determinaticn should be made by indivicuals expert in pressure vessel manufacturing, testing, -operation and maintenance practices regarding the lifetime of these cylinders and their cor:inued use for HEU storage and transportation.

3. Expedite procurement of replacement cylinders.

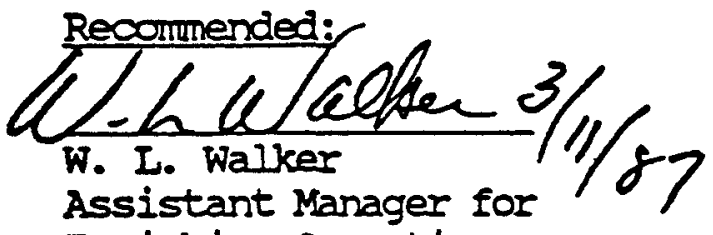

Enriching Operations

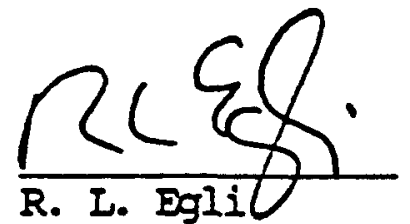

Assistant Manager for Safety \& Envirorment

Aporoved:

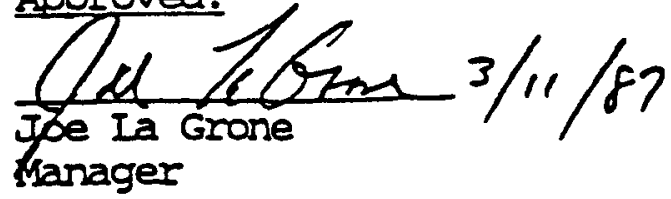


APPENDIX II

Independent consultant Report

$-14-$ 


\title{
A PRELIMINARY REPORT
}

TO:

MARTIN MARIETTA ENERGY SYSTEMS, INC.

P.0. BOX 628

PIKETON, OHIO 45661

\author{
PREPARED BY: \\ WELDING CONSULTANTS, INC. \\ 889 N. 22ND STREET \\ COLUMBUS, OHIO 43219 \\ WILLIAM A. SVEKRIC, P.E. \\ APRIL 13, 1987
}

SUBJECT :

SPECIAL WITHDRAWAL CYLINDER

REFERENCE SPECIFICATION:

CARBIDE AND CARBON CHEMICALS COMPANY

A DIVISION OF UNION CARBIDE AND CARBON CORPORATION

JOB SPECIFICATION JS-1018, ISSUED 4/7/53

REFERENCE DRAWING:

CARBIDE AND CARBON CHEMICALS COMPANY

C-KP-K3969, DRAWN 2/18/53, CHECKED 4/8/53

REFERENCED CODE PARAGRAPH:

1949 CODE FOR UNFIRED PRESSURE VESSELS, ASME, PAR. U-69 


\section{บUVR]}

889 N. 22nd Street Columbus, Ohio 43219

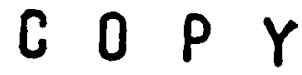

(614) $258-7018$

SPECIAL WITHDRAWAL CYLINDER

\section{WORK STATEMENT}

On March 18, 1987 a meeting was attended at Martin Marietta Energy Systems, Inc. Piketon, Ohio. At that time we accepted the task of reviewing the history of the Model 5A Special Withdrawal Cylinder including necessary repairs and modifications with a view to the Code status of the vessels. Specifically, we were to:

1. Determine if the $5 \mathrm{~A}$ cylinders could be Code stamped.

2. Assess the cylinder integrity considering design review, modification design, methods, procedures, test data, service history and use conditions.

3. Offer an opinion, if the vessels cannot be Code stamped, as to their use until Coded vessels are able to be obtained.

\section{BACKGROUND}

It is our understanding that Martin Marietta is the holder of an "R" stamp which permits them to make repairs to vessels, but not modifications. A modification would not be limited to, but would include, any change to the original design or material specification. It was explained that over the years nozzle material as well as nozzle design have been changed to eliminate problems of liquid metal embrittlement from brazing and to make welding easier. Other material changes may have been made as well. For a "U" stamp holder this would not be a problem; unfortunately, Martin Marietta is not a "U" stamp holder. One additional problem reported is that the new material was purchased without mill test reports.

Design conditions have not been changed and are given below:

Design Pressure and Temperature: Vacuum at Minus $100 \mathrm{Deg}$. F. Design Pressure and Temperature: 200 psig at 250 Deg. F.

Corrosion Allowance:

Hydrostatic Test:

None

400 psig

In addition to the hydrostatic test noted above, the original specification required vacuum testing with a limited leak rate. A test note on original drawing E-F0288X-A specifies the mass spectrometer method. Impact testing at low temperature not required. 
Special Withdrawal Cylinder

Martin Marietta Energy Systems, Inc.

Martin Marietta furnished various drawings and specifications for review. It is assumed that the earliest versions available were provided. The oldest drawing was Goodyear DX-C1018-M1, Product Withdrawal Cylinder, drawn $6 / 21 / 51$, checked 6/27/51. The oldest specification was Carbide and Carbon Chemicals Company JS-1018, dated 4/7/53. The newest drawings bear dates from 1977 to 1986. The changes noted during the review appear in Table I.

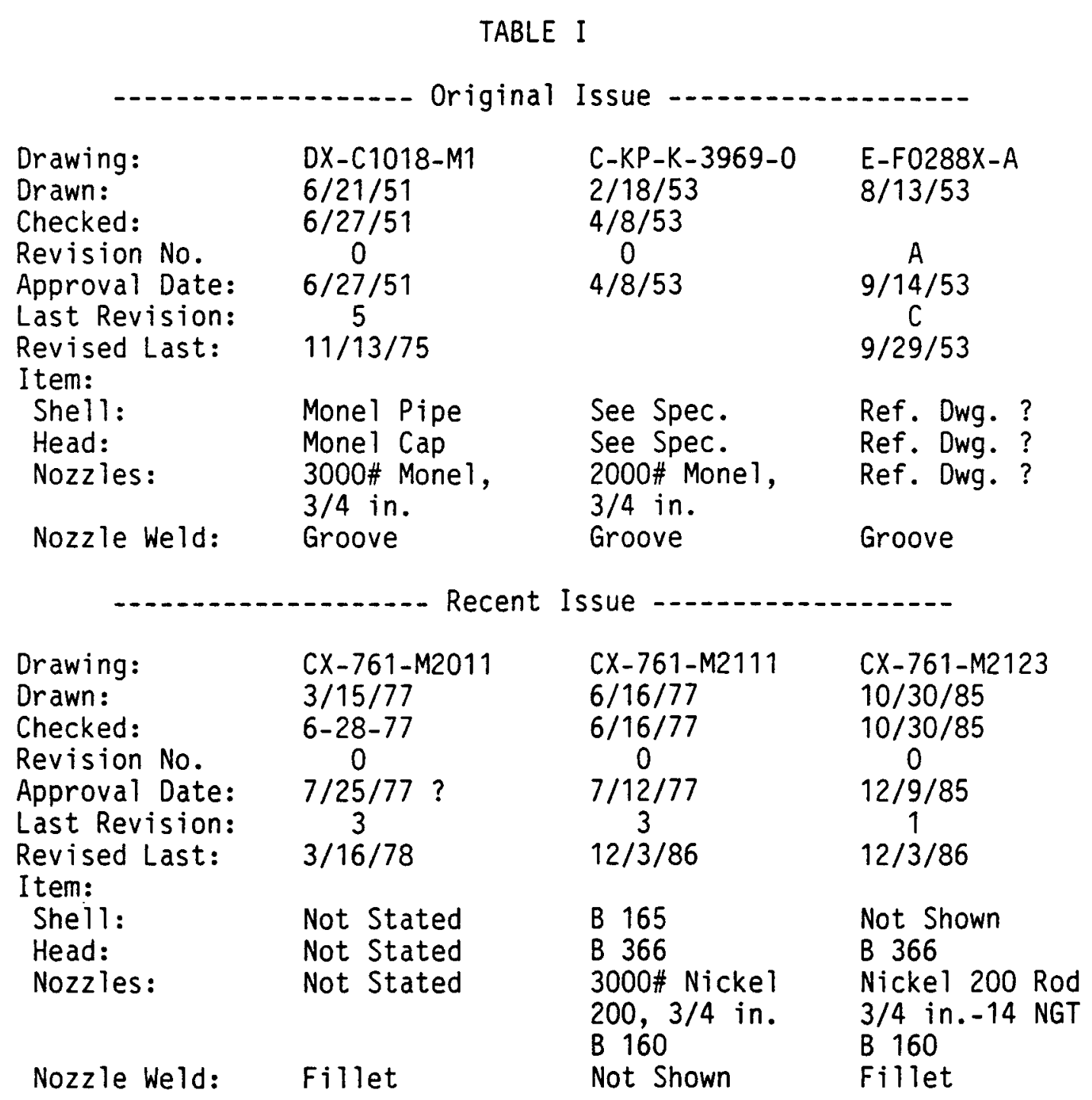

Note: Job Specification JS-1018 Item 4B, Paragraph B2, Material, stipulates monel ASTM B 164 "billet" process or B 165 for seamless pipe. Monel fittings and ASTM B 164 couplings with 2000 lb. classification. 
Special Withdrawal Cylinder

Martin Marietta Energy Systems, Inc.

Page Three

1949 ASME CODE DESIGN

Shell Material:

Specified to be 5 in. seamless monel schedule 40 pipe, ASTM B 165 . From Table U-3 the maximum allowable design stress is listed as 13,000 psi for a temperature range from subzero to $700 \mathrm{deg}$. F.

Job Specification JS-1018 stipulates welded construction in accordance with the 1949 ASME Code, paragraph U-69. U-69, among other things, limits the joint efficiency, $E$, to 0.80 . Other limitations of U-69 include maximum thickness at joints and maximum pressure which do not apply for this case. U-69 requires qualified welding procedures and operators. Since paragraph

$\mathrm{U}-20$ is referenced, it is the next place to check compliance.

Paragraph U-20 covers Shells for Internal Pressure. The information required is as follows:

$S$ from U-3: 13,000 psi $E$ from U-69: $0.80 \quad R$ inside: 2.524 in.

The formulas may be used if $t$ is not over $R / 2$. $R / 2$ is 1.262 in. and $t$ for the 5 in. schedule 40 pipe is 0.258 in., since $t$ is less than $R / 2$ use of the formulas is permitted.

$$
\begin{aligned}
& U-20 \text { (a) } P=(S E t) /(R+0.6 t) \quad t=(P R) /(S E-0.6 P) \text { Where: } \\
& =2,002 \text { psi }=0.049 \text { in } P=\text { max. pressure }
\end{aligned}
$$

U-20(d) covers vessels subject to External Pressure and references paragraphs U-120 to U-138 or U-51. U-20(e) is not applicable as it covers Tubes and Pipes Used as Tubes. U-120 covers Cylindrical Vessels Subjected to External Pressure when constructed of steel complying with a list of specifications. This list only includes steel so the vessel material proposed is not included. This means that the rules covered in paragraphs U-120 to U-138 do not apply. Paragraph U-51 covers Hydrostatic Deformation Testing and references paragraphs UA-1 to UA-11 or the Boiler Code Committee. These Appendix paragraphs address a method of determining the Proportional Limit of a material by using a pressure test. This information is not, further, covered in the Code. The message is that the Boiler Code Committee would have to be consulted before proceding with the design.

The thickness of the end caps is covered by U-36 Dished Heads. Basically, a 2:1 ellipsoidal pipe cap equal to the shell thickness is acceptable. Nozzles were not considered, since the external pressure is not calculable to Code. 


\section{ASME CODE DESIGN}

A review of the 1952 Code reveals exactly the same problem as the 1949 Code. No charts are provided for use in determining a design for external pressure. A general chart for Nickel-Copper is provided in the 1954 addenda. It is not known if this chart was available in 1953 when the vessels, apparently, were released for fabrication.

\section{ASME CODE DESIGN USING BLUE ADDENDA}

Without going into all of the calculations it is possible to design a vessel complying with the rules of this Code. Either the original monel, monel with nickel nozzles or an all nickel vessel can be designed to meet the Code. A trial calculation for the original unmodified vessel resulted in a Codable vessel with a maximum allowable working pressure of over 1,300 psi.

\section{SHOP VISIT}

During one visit the following areas were toured:

Valve testing (Hydro Shop) Machine Shop

Valve repair

New repair area

The areas were well equipped and seemed to be functional with the exception of the new repair area which was still being completed. The new area promises to be a roomy, clean and efficient work place.

\section{DOCUMENTATION}

After the shop tour welding procedures, welder performance qualification test results and a quality assurance manual were reviewed and explained. Records and procedures appeared to be up to date and being followed. Lists of welders are maintained by department and as a group. The group listing indicates which individuals must be utilized to maintain certification and any individuals that will have to be recertified. Sample forms for inspection results appeared to be adequate for the work at hand.

\section{RADIOGRAPHY}

During the same visit some sample radiographs and reader sheets were reviewed and found to be in order. The radiography is not necessarily required by Code, but does offer some extra evidence of quality. 


\section{CONCLUSIONS}

It appears that a recent review of the subject vessels has resulted in their Codability being questioned. Considering the lack of a "U" stamp and the use of unidentified materials this questioning is valid.

Based on the above information it would appear that the vessel designs to the 1949 and/or 1952 Codes should not have been attempted without some destructive proof testing and some submittals to the Boiler Code Committee. Documentation should be sought unless the vacuum leak test is considered adequate proof of the ability to resist external pressure.

Changes since that time have not improved the situation. The use of new materials without a "U" stamp is not permitted. Use of materials without mill test reports is not permitted. The change in specification from ASTM B 164 and/or B 165 to B 366 is not significant. The B 366 specification is fairly new and covers many nickel alloys for welding fittings including ASTM B 164 and B 165 .

Clearly, the vessels are not, currently, Code acceptable nor will it be possible to bring them into Code compliance without extensive rework. Reinstatement would require replacement of all materials without mill test reports. Further, a new set of design calculations to a newer version of the Code would be required.

Considering the results of the design to the 1986 Code and the test results reported during the meetings the servicability of the vessels can be demonstrated. We, also, know this because the vessels are being used as originally intended every day without problems.

It is the considered opinion of this writer that the vessels as they now exist will with proper maintenance continue to perform satisfactorily for many additional years of service.

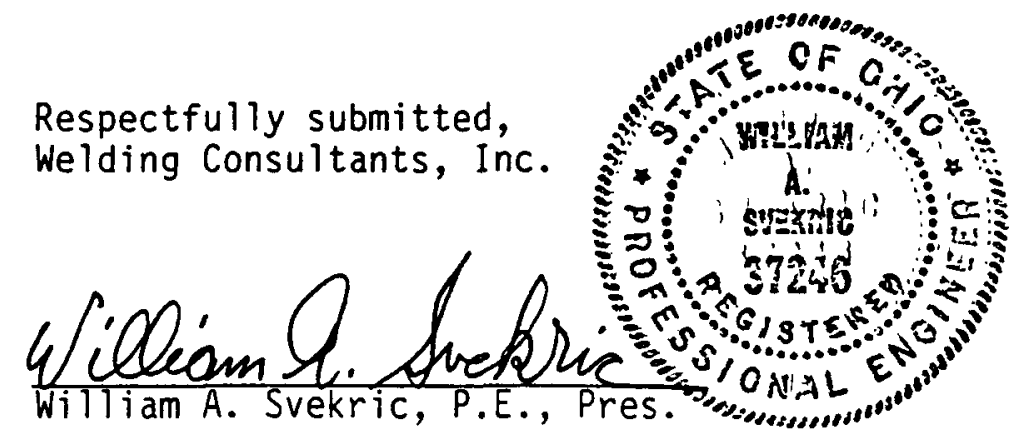

Iwas

CC: File H-158 